\title{
Guru Gobind Singh Ji: A Great CEO.
}

\author{
Prof. (Dr.) Markanday Ahuja ${ }^{1}$, Ms. Jaspreet Bajaj ${ }^{2}$ \\ ${ }^{I}$ Vice Chancellor, Baba Mastnath University, Asthal Bohar, Rohtak \\ ${ }^{2}$ Research Scholar, Deptt. of Management, Baba Mastnath University, Asthal Bohar, Rohtak
}

\begin{abstract}
The main objective of this research paper is to find out the managerial sagacity from the life history of the Guru Gobind Singh which can sensitize the global business leaders towards value-based management for sustainable growth and success. Managers can build ethical socially responsible organizations by imbibing the Sikh model of ethical managerial conduct and can initiate a move to come out of the vicious circle of ailments prevailing in the society and system. It will lead to a situation where one can remain detached as the lotus in the filthy water remains detached.
\end{abstract}

\section{Sikhism}

Sikhism meaning a disciple, or a learner, is a monotheistic religion that originated in India during the 15th century. The fundamental beliefs of Sikhism include faith in one Creator God, unity and equality of all humankind, engaging in selfless service, striving for social justice, and honest conduct and livelihood while living a householder life. With over 25 million adherents worldwide, Sikhism is an Indian religion spread out around the world. Sikhism is based on the spiritual teachings of Guru Nanak, the first Guru, and the nine successive Sikh gurus. After the death of the tenth Sikh Guru, Guru Gobind Singh, the Sikh scripture Guru Granth Sahib became the literal embodiment of the eternal, impersonal Guru, where the scripture's word serves as the spiritual guide for Sikhs. Sikhism considers spiritual life and secular life to be intertwined. Guru Nanak established the system of the Langar, or communal kitchen, in order to demonstrate the need to share and have equality between all people. Sikhs also believe that all religious traditions are equally valid and capable of enlightening their followers, rejecting the practice of proselytism, and rejecting any claims that a particular religious tradition has a monopoly on Absolute Truth. Guru Nanak advocated sharing with others, earning an honest living without exploitation and the need for remembrance of the divine name (God). Guru Nanak taught that living an "active, creative, and practical life" of "truthfulness, fidelity, self-control and purity" is above the metaphysical truth, and that the ideal man is one who "establishes union with God, knows His Will, and carries out that Will". Guru Hargobind, the sixth Sikh Guru, established the political/temporal (Miri) and spiritual (Piri) realms to be mutually coexistent.

\section{Ten Gurus And Authority ${ }^{1}$}

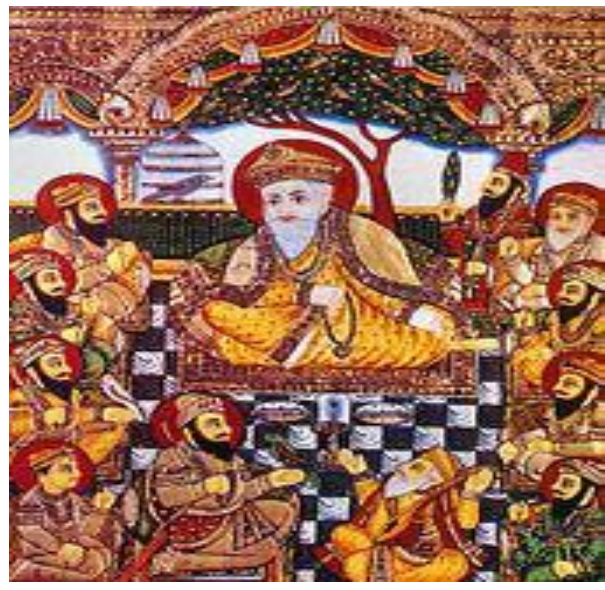

1 Singh, Khushwant (2006). The Illustrated History of the Sikhs. India: Oxford University Press. p. 15. ISBN 978-0-19-567747-8. 


\section{A rare Tanjore-style painting from the late 19th century depicting the ten Sikh Gurus with Bhai Bala and Bhai Mardana}

The term guru comes from the Sanskrit guru, meaning teacher, guide, or mentor. The traditions and philosophy of Sikhism were established by ten specific gurus from 1469 to 1708. Each guru added to and reinforced the message taught by the previous, resulting in the creation of the Sikh religion. Guru Nanak was the first guru and appointed a disciple as successor. Guru Gobind Singh was the final guru in human form. Before his death, Guru Gobind Singh decreed that the Guru Granth Sahib would be the final and perpetual guru of the Sikhs. Guru Angad succeeded Guru Nanak. Later, an important phase in the development of Sikhism came with the third successor, Guru Amar Das. Guru Nanak's teachings emphasised the pursuit of salvation; Guru Amar Das began building a cohesive community of followers with initiatives such as sanctioning distinctive ceremonies for birth, marriage, and death. Amar Das also established the manji (comparable to a diocese) system of clerical supervision.

Guru Amar Das's successor and son-in-law Guru Ram Das founded the city of Amritsar, which is home of the Harimandir Sahib and regarded widely as the holiest city for all Sikhs. Guru Arjan was captured by Mughal authorities who were suspicious and hostile to the religious order he was developing. His persecution and death inspired his successors to promote a military and political organization of Sikh communities to defend themselves against the attacks of Mughal forces.

The Sikh gurus established a mechanism which allowed the Sikh religion to react as a community to changing circumstances. The sixth guru, Guru Hargobind, was responsible for the creation of the concept of Akal Takht (throne of the timeless one), which serves as the supreme decision-making centre of Sikhism and sits opposite the Harmandir Sahib. The Sarbat Khalsa (a representative portion of the Khalsa Panth) historically gathers at the Akal Takht on special festivals such as Vaisakhi or Hola Mohalla and when there is a need to discuss matters that affect the entire Sikh nation. A gurmata (literally, guru's intention) is an order passed by the Sarbat Khalsa in the presence of the Guru Granth Sahib. A gurmata may only be passed on a subject that affects the fundamental principles of Sikh religion; it is binding upon all Sikhs. The term hukamnama (literally, edict or royal order) is often used interchangeably with the term gurmata. However, a hukamnama formally refers to a hymn from the Guru Granth Sahib which is a given order to Sikhs.

\section{Guru Granth Sahib}

The final version of the Guru Granth Sahib was compiled by Guru Gobind Singh in 1678. It consists of the original Adi Granth with the addition of Guru Tegh Bahadur's hymns. The Guru Granth Sahib is considered the Eleventh and final spiritual authority of the Sikhs.

(आज्ञा भई अकाल की, तबे चलायो पंथ।

सब सिखन को हुक्म है, गुरु मान्यो ग्रन्थ।

गुरु प्रंथ जी मानओ, प्रगट गुरं के देह।

जा का हिरदा शुद्ध है, खोज शब्द में ले।)

The text comprises 6,000 sabads (line compositions), which are poetically rendered and set to rhythmic ancient north Indian classical form of music. The bulk of the scripture is classified into thirty one ragas, with each Granth raga subdivided according to length and author. The hymns in the scripture are arranged primarily by the ragas in which they are read. The main language used in the scripture is known as Sant Bhașa, a language related to both Punjabi and Hindi and used extensively across medieval northern India by proponents of popular devotional religion (bhakti). The text is printed in Gurumukhi script, believed to have been developed by Guru Angad, but it shares the Indo-European roots found in numerous regional languages of India.

\section{Guru Gobind Singh Ji}

The tenth and the last Guru or Prophet-teacher of the Sikh faith, was born Gobind Rai Sodhi on Poh 7, 1723 sk/22 December 1666 at Patna, in Bihar. His father, Guru Tegh Bahadur, the Ninth Guru, was then travelling across Bengal and Assam. Returning to Patna in 1670, he directed his family to return to the Punjab. On the site of the house at Patna in which Gobind Rai was born and where he spent his early childhood now stands a sacred shrine, Takht Sri Harimandar Sahib, one of the five most honoured seats of religious authority (takht, lit. throne) for the Sikhs. Gobind Rai was escorted to Anandpur (then known as Chakk Nanaki) on the foothills of the Sivaliks where he reached in March 1672 and where his early education included reading and writing of Punjabi, Braj, Sanskrit and Persian. He was barely nine years of age when a sudden turn came in his life as well as in the life of tile community he was destined to lead. Early in 1675, a group Kashmiri Brahmans, drivels to desperation by the religious fanaticism of the Mughals General, Iftikar Khan, visited Anandpur to seek 
Guru Tegh Bahadur's intercession. As the Guru sat reflecting what to do, young Gobind Rai, arriving there in company with his playmates, asked Why he looked so preoccupied. The father, as records Kuir Singh in his Gurbilas Patshahi 10, replied, "Grave are the burdens the earth bears. She will be redeemed only if a truly worthy person comes forward to lay down his head. Distress will then be expunged and happiness ushered in." "None could be worthier than yourself to make such a sacrifice," remarked*Gobind Rai in his innocent manner. Guru Tegh Bahadur soon afterwards proceeded to the imperial capital, Delhi, and courted death on 11 November 1675 .

Guru Gobind Singh was formally installed Guru on the Baisakhi day of 1733 Bk/29 March 1676. In the midst of his engagement with the concerns of the community, he gave attention to the mastery of physical skills and literary accomplishment. He had grown into a comely youth spare, lithe of limb and energetic. He had a natural genius for poetic composition and his early years were assiduously given to this pursuit. The Var Sri Bhagauti Ji Ki, popularly called Chandi di Var. written in 1684, was his first composition and his only major work in the Punjabi language. The poem depicted the legendary contest between the gods and the demons as described in the Markandeya Purana. The choice of a warlike theme for this and a number of his later compositions such as the two Chandi Charitras, mostly in Braj, was made to infuse martial spirit among his followers to prepare them to stand up against injustice and tyranny.

\section{Management Perspectives Of Sikh Religion}

Sikhism, the fifth largest and one of the youngest religions of the world is considered as the most down to earth and practical religion of the world. It is a religion of the new age. It is an egalitarian religion which preaches a message of love, devotion, truthful living, liberty, equality, fraternity and remembrance (Simran) of God at all times. It is a universal faith with a message of peace and prosperity for the whole world. It is a life affirming faith with positive attitude and high spirits. It is heartfelt adoration, devotion and surrender to one God. It is a thoroughly modern and progressive religion which evolved in India as a solution to the catastrophe that plagued Indian society in the fifteenth century.

The credit goes to Guru Nanak that he introduced real reforms and laid the foundation on which his successor, the tenth Sikh Master, Guru Gobind Singh created a new nation. Guru Nanak saved his followers from those shortcomings to which the disciples of many other religions had been falling prey to for centuries. He taught the people worship of God and purity of character. In this way, he started a new religion which was simple, independent, non-communal and free from rites and rituals.

\section{Management And Sikhism}

Sri Guru Granth Sahib gives message for spiritual development as well as human development including management effectiveness. Sri Guru Granth Sahib has many treasures to contribute in different areas of management like leadership, motivation, ethics and CSR. It is a store-house of knowledge which teaches selfdiscipline and control as only a person who can control his mind and reactions can control/manage an organisation and people in it and attain managerial excellence. As long as the manager's mind remains an unconquered enemy, the manager has to serve the dictation of anger, greed, lust, illusion, etc and this may result management failure however when the mind is conquered, the manager will have no difficulty in achieving their organisational goals.

Sri Guru Granth Sahib helps develop the sense of service and sense of sacrifice for others which help individuals to evolve as better human beings and better organizers consequently they develop a higher and broader vision and work not for the benefit of one but for the larger benefit of all. A perfect being is described in the Sikh Scripture, as, "One who revels in doing good to others". Altruistic action and right character take precedence in the Sikh Scheme of values. The Sikh heritage reminds the spiritual seeker of the social obligations of society, namely that the spiritual guest in not only vertical but horizontal as well. The affairs of human life are essential considerations to a spiritually aware individual. The Sikh religion strives to create an ideal society that has as its basis spiritual awareness and ethical integrity. In short, Sikhism expounds the ideals of a cultured person who lives holistically with inner awareness of the Lord and with the purpose of serving the nation selflessly. Thus, the present study, Management Perspectives in Sikhism is an attempt to find out the wisdom and sagacity of the Sikh Gurus and Sikh Scripture Sri Guru Granth Sahib in the light of management paradigms of today.

\section{Statement of the problem: \\ Guru Gobind Singh Ji: A Great CEO \\ Need of the study:}

"All progress is born of enquiry. Doubt is often better than over confidence for it leads to enquiry, and enquiry leads to invention." 
Increased scientific and inductive thinking and it promotes the development of logical habits of thinking and organization. Research has its special significance in solving various operational and planning problems of business and industry. Research, along with motivational research, are business decisions, research is the investigation of the structure and development of the organization for the purpose of formulating efficient policies for running it smoothly.

\section{Objectives of the study:}

The study is based on following objectives:

1. To know about the Sikhism.

2. To know about the personality of Guru Gobind Singh Ji.

3. To find out the inborn managerial qualities of Guru Gobind Singh Ji.

\section{Research Design}

A research design is the arrangement of condition for collecting and analysis of data in a manner that aims to combine relevance to the research purpose with economy in the procedure. Research designs are of four types namely:

- Exploratory (formulative),

- Descriptive

- Diagnostic and

- Experimental.

In the present study, descriptive research design has been adopted.

\section{Collection Of Data}

There are two types of data collection methods namely primary data and secondary data. The present study is entirely based on secondary data. Though, the scope of the study is purely historical. Therefore, secondary data have been used in the present study. The secondary data has been collected from various journals, books, magazines and newspapers. For this purpose, researcher visited many libraries. Some important information/knowledge was also gathered from Internet. All the gurudwaras and temples were personally visited by the researcher and requested to provide needed information.

\section{Secondary Data Analyses}

As this was an historical research, the researcher adopted the secondary source of data for the collection of data. Therefore, the researcher adopted the descriptive analysis approach of the secondary data. Researcher collected the data from the secondary sources (i.e. Holy Granths, journals, books, magazines and newspapers) and processed them to reach at a conclusion and to answer the research question. All the findings and conclusion drawn from the secondary data analysis.

\section{Findings of the study:}

Clear plan and vision:

At a time when there was communal disharmony and rulers and emperors repressed and exploited the common people, Guru Gobind Singh came with a mission to disseminate the spirit of universal brotherhood. He envisioned a classless and casteless society and planned to introduce an independent and distinct spiritual system.

\section{Effective communication:}

To spread the message of brotherhood and peace, Guru Gobind Singh travelled all over the country and even outside it. He visited numerous places of Hindu and Muslim worship. In those times illiteracy was rampant. He reached out to people at grass-root level through his travels and spread his ideas far and wide, thereby gaining popularity for the Sikh religion. He used interactive approach for conversing with the people.

\section{Path of truth and enlightenment:}

Guru Gobind Singh carried the torch of truth on his voyages and enlightened people who were suffering out of hatred, falsehood, greed and hypocrisy. He travelled and taught through practice and precept. On the banks of river Ganga, he cautioned people offering water to their dead ancestors in the region of Sun to quench their thirst, against false rituals and superstitions and directed them to follow the path of truth and enlightenment. 


\section{Concept of social responsibility:}

Guru Gobind Singh asserted the importance of helping the needy and the poor. He himself always helped the poor and he served food to them. Guru asserted that helping the destitute by activities like feeding the hungry and providing clothes to the naked makes the donor a recipient of God's grace, and emphasized that such donations should be made out of one's honest earnings.

\section{Re-engineering of personalities:}

Guru Gobind Singh never ignored or out-casted people who did not possess good personalities but worked to reform and re-engineer them and was able to transform them into fine individuals.

\section{Equality of mankind:}

Guru Gobind Singh gave the message of equality of mankind. He taught that God has created the universe and he is everywhere and in every being. So, one cannot discriminate people on the basis of caste and creed etc. when God has created them as equals. He introduced the practice of community kitchen where people from all castes and creeds sat together to eat without any distinction of social hierarchy.

\section{Cultivation of inner strength:}

Guru Gobind Singh accentuated the value of virtues of the human character and advised control of vices. The vices like ego, anger, greed, lust and vanity can be conquered through self-examination and selfrealization. He said, "See the brotherhood of all mankind as the highest order of Yogis; conquer your own mind, and conquer the world"

\section{Conclusion:}

The lessons of managerial sagacity from the life history of the Gurus Gobind Singh can sensitize the global business leaders towards value-based management for sustainable growth and success. Collective wisdom of the great Gurus calls for a manager to be selfless and his style to be the one which is drenched with virtues and shared values with the general well being of all as the core concern. Congruence in pious thoughts, sincere words and actions for the good of all was the greatest motivator for the followers of the Gurus Gobind Singh so the need of the hour is for the leaders who are true to their word. Managers can build ethical socially responsible organizations by imbibing the Sikh model of ethical managerial conduct and can initiate a move to come out of the vicious circle of ailments prevailing in the society and system. It will lead to a situation where one can remain detached as the lotus in the filthy water remains detached.

\section{References}

[1]. Singh, Khushwant (2006). The Illustrated History of the Sikhs. India: Oxford University Press. p. 15. ISBN 978-0-19-567747-8.

[2]. Chahal, Devinder (July-December 2006). "Understanding Sikhism in the Science Age" (PDF). Understanding Sikhism, The Research Journal (2): 3. Retrieved 10 November 2013.

[3]. Chahal, Amarjit Singh (December 2011). "Concept of Reincarnation in Guru Nanak's Philosophy" (PDF). Understanding Sikhism The Research Journal 13 (1-2): 52-59. Retrieved 29 November 2013

[4]. Duggal, Kartar Singh (1988). Philosophy and Faith of Sikhism. Himalayan Institute Press. p. 15. ISBN 978-0-89389-109-1.

[5]. Ethical issues in six religious traditions By Clive Lawton, Peggy Morgan Section C.4.e. ISBN B001PC20N2

[6]. Priyavrat Thareja \& Amrinder Singh Chahal (2011), "The 14 Principles Guru Gobind Singh Cultivated to Societal Stability", Department of Materials and Metallurgical Engineering, PEC University of Technology, Chandigarh, p. 26-39.

[7]. $\quad$ Kuldeep Singh (2002), "Business Ethics in Sikh Tradition", Oakland University, p.61-63.

[8]. Dharminder Singh Ubha (2007), "Corporate Governance: Solutions through Indian Spiritual System”, Regional Training Institute, Allahabad, p. 104-108.

[9]. Gurwinder Kaur (2008), "The Concept of Ideal Man in Guru Nanak Bani", Gurmat Prakashan, U.S.A., p.65-66. 